\title{
Doświadczenie czasu pandemii w późnym kapitalizmie ${ }^{1}$
}

\section{Abstract \\ The Experience of Pandemic Time in Late Capitalism}

The subject of the article is the transformation of social time in the pandemic reality. The situation caused by COVID-19 provided a unique opportunity to observe sudden changes in the social rhythm. In the considerations conducted from the perspective of time studies, the author tries to specify what these changes are, and also considers how social time is shaped in the economy of late capitalism. The observations show that changes in the organization and experience of social time during a pandemic are shaped mainly on the basis of three categories: power, technology and work. The experience of the crisis of the usual feeling of time and of the uncertainty about the future, resulted in the rise of questions pertaining to the new concepts of time, the effects of this transformation and the upcoming social changes.

Keywords: social time, pandemic time, power, technology, work, late capitalism

Sytuacja wywołana przez COVID-19 przyniosła różnorodne zmiany w doświadczaniu czasu. Choć podstawowe założenia badań nad współczesnym czasem społecznym pokazują znaczenie wielu czynników kształtujących go, to uważam, że najważniejszymi z nich są władza, technologia i praca. To głównie z tych elementów uformowały się dotychczasowe rytmy późnego kapitalizmu (Hassan 2009).

${ }^{1}$ Artykuł stanowi uzupełnienie interpretacji wyników badawczych uzyskanych w ramach projektu „Aranżowanie temporalności: kulturowe praktyki zarządzania czasem” nr 2017/27/N/HS3/00479 finansowanego przez Narodowe Centrum Nauki. Podczas projektu zostało zrealizowanych 57 wywiadów prowadzonych zgodnie z kwestionariuszem badawczym, dostępny na stronie internetowej projektu: choreography-of-time.weebly.com/uploads/6/7/7/5/67758073/ethnographic_interview_questions_in_polish_ language.pdf. 
Pragnę wykazać, że ich rola była kluczowa $\mathrm{w}$ transformacji czasu pandemicznej rzeczywistości społecznej. Do tych najważniejszych kategorii (władzy, technologii i pracy) odnoszą się trzy podtytuły artykułu, które porządkują strukturę wywodu: 1) polityka czasu pandemii; 2) wpływ nowych technologii na doświadczenie czasu w trakcie pandemii; 3) czas pandemii a praca.

Przyglądając się przekształceniom $\mathrm{w}$ doświadczeniu czasu społecznego, w trakcie pierwszych trzech miesięcy od wybuchu pandemii w Polsce prowadziłam swobodne rozmowy na temat odczuwania zachodzących zmian spowodowanych kwarantanną lub izolacją w domu. Przeważnie podczas wideokonferencji dyskutowałam z osobami, z którymi pół roku wcześniej przeprowadzałam wywiady w ramach realizowanego projektu badawczego na temat kulturowych praktyk zarządzania czasem w neoliberalizmie. Mając na uwadze rozproszony charakter zjawiska czasu pandemii, przytaczam w tekście również różnorodne materiały internetowe powstałe w $2020 \mathrm{r}$. Wśród nich znalazły się artykuły prasowe i naukowe, wywiady, akty prawne, nagrania, blogi oraz publikowane $\mathrm{w}$ internecie memy komentujące pandemiczną rzeczywistość i stanowiące niezwykle cenne świadectwo nowych porządków czasowych. Zebrany materiał przeanalizowałam pod kątem władzy, technologii i pracy - elementów silnie wpływających na formę czasu społecznego późnego kapitalizmu.

Pierwszy przypadek zakażenia koronawirusem w Polsce został oficjalnie zarejestrowany 4 marca 2020 r. Od tego momentu prędkość zakażeń i globalny wymiar rozprzestrzeniania się COVID-19 spowodowały, że ogromna liczba osób przebywała tygodniami w domu. $\mathrm{W}$ efekcie nastąpiła nagła społeczna zmiana w sposobach doświadczania czasu. W ciągu niespełna miesiąca urzeczywistnił się niemożliwy do zaaranżowania w kontrolowanych warunkach eksperyment chronobiologiczny o niespotykanej dotąd skali. Trwająca pandemia, ogłoszona przez WHO 11 marca, okazała się wyjątkową okazją, aby zaobserwować przeobrażenia społecznego rytmu, które zwykle dokonują się w trudnym do uchwycenia przez badaczy, powolnym procesie. Zasięg tego nieplanowanego eksperymentu jest nieporównywalny $\mathrm{z}$ rezultatami dotychczas przeprowadzanych badań związanych z czasem, takich jak te przeprowadzone przez Michela Siffrea na sobie samym. Francuski geolog w 1962 r. przez 61 dni przebywał w głębi zlodowaciałej alpejskiej jaskini w warunkach całkowitego odcięcia od wszystkich wskazówek i miar, na skutek czego stracił rachubę i orientację w czasie (Klein 2009: 17-26) ${ }^{2}$. W podobny sposób pandemia COVID-19 i związana z nią konieczność nieustannego prze-

\footnotetext{
2 Siffre przez cały czas eksperymentu przebywał na głębokości 130 metrów i za pośrednictwem telefonu polowego przekazywał informacje, kiedy układa się do snu, wstaje, je oraz jak długo według własnej oceny siedzi po ciemku. W efekcie geolog zupełnie utracił rachubę czasu, ponieważ został odcięty od wskazówek i miar orientacji w czasie, takich jak wschody i zachody słońca. Jednak mimo kompletnej utraty poczucia czasu w jego organizmie ustalił się precyzyjny, indywidualny rytm. Doba badacza trwała 24,5 godziny, zaś czas czuwania 16 godzin. Jego czas biologiczny stał się jego jedyną miarą czasu, której nie był świadomy do momentu, gdy nie wyciągnięto go z jaskini i nie przedstawiono wyników badań.
} 
bywania w domu zdążyła wytrącić ludzi z codziennego doświadczenia upływu chwil (Kaur 2020). Globalna skala pandemicznego eksperymentu zmieniającego rytmy czasowe jest doświadczeniem społecznym, co sprawia, że jest to niezwykle ciekawe zjawisko z perspektywy studiów nad czasem (Fraser 1987; Adam 1995, 2008; Strang 2015) czy zwrotem temporalnym (Hassan 2010; Strzelecka 2017b), a także antropologii czasu (Fabian 2002; Gell 1996; Munn 1992) i socjologii czasu (Tarkowska 1987, 1992), przy czym czas społeczny jest rozumiany jako unikalny wzór zachowań i praktyk społecznych, wytwarzany poprzez wspólnotę doświadczeń, związany z działaniami jednostek, grup i instytucji społecznych (Tarkowska 1987: 130).

Nieplanowany eksperyment pandemiczny wywołał kryzys zwyczajowego odczuwania czasu $\mathrm{w}$ wymiarze zarówno indywidualnym, jak i społecznym, zrewaloryzował wyobrażenia i wartości związane z czasem, które wydawały się czymś oczywistym, doprowadził do defamilaryzacji dotychczasowego rozumienia tego, czym jest czas w powszechnej świadomości, a także zwiększył niepewność dotyczącą przyszłości oraz wygenerował pytania o nowe koncepcje czasu i skutki tej transformacji. Chcąc jakkolwiek nazwać i oswoić zachodzące przemiany, zaczęto mówić o "tym dziwnym”, „trudnym”, „niepokojącym” lub też „wyjątkowym" czasie, który wraz ze swym aspektem graniczności i wspólnotowości nabrał cech czasu quasi-liminalnego. W tym przejściowym okresie na nowo zaczął się kształtować społeczny obraz świata, a efektem przeobrażeń są nieznane wcześniej podziały temporalne. Nie istnieje opis czasu pandemii w pełni oddający jego naturę. Nie wiadomo, jak ów czas nazwać ani tym bardziej jak w nim działać. Również niniejszy artykuł nie pretenduje do tego, aby stać się jednolitym opisem czasu pandemii, a jedynie stwarza zarysy pewnych wątków wartych rozważenia.

W obliczu dezorientującej nieokreśloności czasu pandemii, konsekwencji i problemów związanych z utratą kontroli nad czasem zaistniało zjawisko, które można określić „,kalendarzem pandemii”. Wszelkie listy, wykazy, spisy, zestawienia przepełnione datami i liczbami pełnią funkcję urealniającą rzeczywistość, ustanawiają konkretne współrzędne ułatwiające nawigację w odmiennej pandemicznej rzeczywistości. Codziennie szczegółowo konstruowane, uzupełniane o nowe dane i powielane przez kolejne portale informacyjne wyliczenia zaspokajają potrzebę umysłu ludzkiego, tworząc koordynaty, które pozwalają nam określić i nazwać przeżywane doświadczenia ${ }^{3}$. Statystyki zarażeń i zgonów, stale aktualizowane w Wikipedii na podstawie rządowych źródeł, rozmieszczone w chronologicznym układzie, wzdłuż linii czasu, nadają naszym wyobrażeniom pewien ustrukturowany obraz sytuacji. Wykresy, szczególnie krzywa zachorowań, wizualizują rozwój

${ }^{3}$ Przykładowo, portal OKO.press publikował następujące wyliczenia: „10 marca, 6 dni po (pierwszym zidentyfikowanym przypadku koronawirusa), odwołano wszystkie imprezy masowe; 12 marca, 8 dni po, zamknięto szkoły i uczelnie; 15 marca 11 dni po, wprowadzono kordon sanitarny na granicach; 25 marca, 21 dni po, wprowadzono ograniczenia w kontaktach pomiędzy ludźmi” (Jędrysik 2020). 
pandemii w czasie i same w sobie konstytuują czas, zaświadczając o statystycznej regularności zarażeń. Rzeczywistość zaczęła dzielić się na przed pandemią, w trakcie i po niej. Pandemia COVID-19, przerywając dotychczasowy bieg czasu, okazała się wydarzeniem na tyle ważnym, że sama w sobie stała się swoistą miarą społecznego systemu rachuby czasu.

O istotności rozważań nad czasem pandemii świadczy fakt, że zazwyczaj wydarzenia jednostkowe, takie jak kataklizmy, epidemie, powodzie i pożary, odmierzały upływ czasu wśród poszczególnych zbiorowości w społecznościach tradycyjnych (Tarkowska 1992: 23). Jednak w przypadku koronawirusa zmianie postrzegania czasu uległy wszystkie współczesne społeczeństwa późnego kapitalizmu, w których promowane są wartości takie jak otwartość na technologię, efektywność pracy, swoboda i przedsiębiorczość. Będąc obserwatorką i uczestniczką gwałtownych i znaczących zmian w obszarze organizacji pracy i czasu w trakcie rozprzestrzeniania się COVID-19, staram się dookreślić, na czym te zmiany polegają, a także lepiej zrozumieć, jak we współczesnej gospodarce późnokapitalistycznej był dotychczas kształtowany czas społeczny i czemu służył.

\section{Polityka czasu pandemii}

Według Brama Ievena i Jana Overwijka COVID-19 powinien być rozumiany dosłownie i w przenośni jako polityczny aktor będący mutacją w globalnej polityce kapitału prowadzącą do zmiany kapitalistyczno-neoliberalnych rytmów życia (Ieven, Overwijk 2020). Transformacja doświadczania czasu dokonała się na skutek działań władzy państwowej, dla której panowanie nad czasem jest narzędziem kontroli społecznej (Borowiec 2013). Chcąc kontrolować tempo rozprzestrzeniania się koronawirusa, należało zapanować nad czasem obywateli, pozostawiając im jedynie możliwość biernej akceptacji dyscyplinujących mechanizmów. Narzucanie społeczeństwu nowych rytmów i sprawowanie nadzoru nad temporalnością poszczególnych jednostek i całych grup społecznych jest zjawiskiem dobrze opisanym w literaturze, gdzie czas społeczny jest ujmowany nie tylko jako zjawisko będące w nierozerwalnej relacji z władzą (Nowotny 2005; Adam 2008; Koczanowicz 2009), ale wręcz jako narzędzie walki politycznej (Hutchings 2008). Jak pisze Valerie Bryson: „Sposoby, w jakie czas jest wykorzystywany, wartościowany i doświadczany, nie są ani bezdyskusyjne, ani «naturalne»; raczej odzwierciedlają i podtrzymują głęboko zakorzenione wzorce władzy i nierówności. Analiza czasu ma zatem kluczowe znaczenie dla zrozumienia procesów politycznych" (Bryson 2016). Tego rodzaju podejście wydaje się uzasadnione w stosunku do rozważań na temat pandemicznej rzeczywistości, w której wiele wyjątkowych procedur sprawowania władzy wpłynęło na zmianę doświadczania czasu. Zachodzące przemiany w sposobach przeżywania upływu i organizacji czasu, będące skutkiem wybuchu pandemii, można interpretować jako następstwa sprawowania 
kontroli nad temporalnością jednostek i społeczeństwa, rozpatrywać pod kątem mikrofizyki władzy (Foucault 2009) i reżimów czasu stanowiących nowe strategie nacisku ze strony władzy państwowej (Pickering 2004; Sabelis 2007).

$\mathrm{W}$ trakcie pandemii sprawowanie kontroli nad tempem czasu dokonywało się na szczeblu państwowym poprzez podejmowanie decyzji i wydawanie rozporządzeń, które spowodowały chociażby zamknięcie instytucji i miejsc publicznych. Na doświadczenie upływu czasu wpływ miały liczne nakazy i zakazy, które na terenie Rzeczpospolitej Polskiej wprowadziła Rada Ministrów: ograniczenie swobody przemieszczania się, w tym ograniczenie ruchu granicznego na określonych przejściach granicznych (Dz.U. 2020 poz. 435), nakaz odbycia obowiązkowej kwarantanny po przekroczeniu granicy (Dz.U. 2020 poz. 491), a także zakaz przemieszczania się z wyjątkiem koniecznych potrzeb życia codziennego (Dz.U. 2020 poz. 522). Stosowane przez władzę strategie nacisku przybrały również formę kar administracyjnych, nakładanych przykładowo za opuszczanie domu w przypadku naruszenia obowiązku kwarantanny lub izolacji. W panowaniu nowych reżimów czasu nad społeczeństwem pomogła technologia - aplikacja Kwarantanna domowa, za pomocą której policja nadzorowała osoby objęte zakazem wychodzenia z domu. Dodatkowo obowiązek utrzymania dwumetrowej odległości między pieszymi wpłynął na reorganizację przestrzeni publicznej. Nowe zasady poskutkowały powstaniem długich kolejek ciągnących się na zewnątrz sklepów oraz punktów usługowych. Przez część czasu trwania pandemii wykonywanie codziennych czynności, takich jak robienie zakupów, trwało znacznie dłużej niż dotychczas również z uwagi na obowiązywanie "godzin dla seniorów” od 31 marca do 4 maja, w trakcie których obsługiwano wyłącznie osoby powyżej 65. roku życia. Utrzymywanie dystansu społecznego i samoizolacji w czasach pandemii spowodowało przekształcenie przestrzeni, w której funkcjonujemy na co dzień, co przełożyło się na przeobrażenie naszego doświadczania czasu.

Wobec procedur wprowadzanych przez władzę w czasie pandemii, odczuwanych przez jednostki jako zbyt ograniczające i przytłaczające, dochodziło do drobnych aktów buntu. Widocznym tego przykładem były internetowe protesty przeciwko zakazowi wejścia do lasów, który zaburzył odczucie wyczekiwanego, znanego czasu związanego z nadejściem nowej pory roku - wiosny. $\mathrm{Na}$ aspekt ten wskazała Ewa Bińczyk: „po wprowadzeniu zakazu wstępu do lasów i parków moi studenci pisali mi, że chyba wyjdą na ulicę i zrobią jakąś zadymę, bo zabiera się im wiosnę" (Bińczyk, Sutowski 2020). Nie doszło jednak do masowego buntu przeciwko środkom represji zastosowanym przez rząd, ponieważ koronawirus jako polityczny aktor uzasadniał wprowadzenie licznych restrykcji. Co więcej, konieczność panowania nad czasem obywateli, tłumaczona potrzebą zahamowania rozprzestrzeniania się pandemii, choć była początkowo postawą narzucaną z zewnątrz, to została przez wiele osób przyswojona. Nowo wytworzone imperatywy czasowe zostały w głównej mierze zinternalizowane, dzięki czemu nie był już konieczny nacisk z zewnątrz. Zdyscyplinowane jednostki same zaczęły wymuszać 
na innych przestrzeganie zasad aranżujących nowe reżimy czasu. Przykładem tego była społeczna akcja \#zostanwdomu, której przekaz był masowo powielany przez indywidualnych użytkowników mediów społecznościowych. Co ciekawe, był on również wykorzystywany w celach marketingowych choćby przez operatorów sieci telefonicznej. Nowe reżimy czasu związane z pandemią uległy procesowi utowarowienia czasu znanemu $\mathrm{z}$ analiz dotyczących dynamiki późnego kapitalizmu (Appadurai 2005: 119; Kopka 2013: 200).

Nowoczesna strategia władzy, wprowadzając dla ochrony przed koronawirusem nadzwyczajne środki kwarantanny i izolacji, przyzwyczaiła nas do tego, że utrata wolności i związany z nią nowy sposób doświadczania czasu jest stanem normalnym. Interpretując pandemię COVID-19 jako agambenowski stan wyjątkowy (Agamben 2008), dostrzegamy konsekwencje nadzwyczajnych działań władzy zawieszających dotychczas znany porządek temporalny. Koronawirus wywołał okoliczności, w których wybrane organy władzy państwowej uzyskały nieograniczone pełnomocnictwo do podejmowania decyzji o nadzwyczajnych działaniach transformujących upływ czasu społecznego. 20 kwietnia 2020 r. rozpoczęło się jednak zaplanowane przez Radę Ministrów RP czteroetapowe rozmrażanie gospodarki. Władza zmieniła swój kierunek i strategię działań, a na horyzoncie pojawili się inni politycznie ważni aktorzy - gospodarka i ekonomia. Imperatyw rozwoju gospodarki okazał się tak potężny, że większość ustaleń i regulacji wygaszono. Nowy zespół obostrzeń, nakazów i zakazów, ujarzmiających nasze ciała, związanych z przymusowym pozostaniem $\mathrm{w}$ domu w czasie pandemii, został złagodzony. Późny kapitalizm zaczął upominać się o to, aby nasze ciała mogły na nowo produkować, dystrybuować i konsumować.

\section{Wpływ nowych technologii na doświadczenie czasu w trakcie pandemii}

Za sprawą koronawirusa znaleźliśmy się w ciekawej, choć niełatwej psychologicznie sytuacji konfrontującej nas z problemami cywilizacji, dla której „głównym problemem jest brak czasu, przemęczenie i przesycenie bodźcami" (Bińczyk, Sutowski 2020). Ogromny wpływ na zmianę tempa życia i ukształtowanie czasu społecznego w trakcie pandemii COVID-19 miały nowe technologie, które już wcześniej stanowiły ważny element procesu stopniowego zawłaszczania naszego czasu przez kapitalistyczną logikę wydajności i produktywności (Hassan 2009; Crary 2015). Technologie informacyjne i komunikacyjne (ICT), odkąd powstały, były główną z przyczyn przyspieszenia czy też, jak pisze Marcin Trybulec, „akceleracji czasu" (Trybulec 2009). Nadmierne korzystanie z nich doprowadziło do odczucia ciągłego zmęczenia, deprywacji sensorycznej i desynchronizacji społecznych rytmów (Tomlinson 2007; Davis 2013; Virilio 2000; Rosa 2013). 
Wraz z postępem pandemii ludzie coraz bardziej zwracali się do internetu z nadzieją, że utrzymają relacje społeczne. Jak twierdzi Alek Tarkowski (2020), „stajemy przed wyzwaniem szybkiego zaprojektowania świata społecznego, w którym więzi i kapitał społeczny są utrzymywane online”. Choć nasze ciała pozostały w odosobnieniu, to dzięki środkom komunikacji i technologiom elektronicznym nie zostaliśmy poddani całkowitej izolacji. Nasze kontakty z innymi utrzymywane przez komputery i telefony stały się jeszcze bardziej intensywne również dzięki pośpiesznej reorganizacji edukacji szkolnej i studiów wyższych, które zostały zapośredniczone przez aplikacje do pracy zdalnej, takie jak Zoom, Google Meet czy Microsoft Teams. Choć część wydarzeń i aktywności odwołano, to prawdopodobnie tyle samo lub więcej zostało przeprowadzonych w formie wirtualnej. Dzięki szerokim możliwościom nowych technologii ku sieci zwróciły się muzea, galerie, a nawet teatry. Różne instytucje kultury po zamknięciu swoich siedzib zaczęły organizować liczne wydarzenia online, debaty i dyskusje o literaturze, wirtualne wystawy, oprowadzanie kuratorskie po galeriach sztuki, a nawet festiwale filmowe. Kultura online nabrała nowej jakości, a o jej rozwój zadbało przykładowo Narodowe Centrum Kultury, które uruchomiło program dotacyjny „Kultura w sieci” (Narodowe Centrum Kultury 2020).

Dzięki technologii czas na powrót zaczął płynąć w przyspieszonym tempie. Odbiorcy kultury i edukacji, przeniesionych na platformy internetowe, jeszcze bardziej zaczęli odczuwać sensoryczne przestymulowanie i wyczerpanie nasilonym szumem medialnym, również tym związanym $\mathrm{z}$ nieustannymi komunikatami dotyczącymi rozwoju pandemii. Zdalna edukacja dla wielu osób okazała się zbyt męczącym doświadczeniem powodującym rozdrażnienie. Nagłe przekształcenie szkolnictwa i innych obszarów życia na format online doprowadziło do nagłego przyspieszenia procesu cyfrowej transformacji, drugiej rewolucji informacyjnej o trudnych do przewidzenia konsekwencjach (Kornbluh 2020). Wybitny pisarz Jacek Dukaj stwierdził, że „wirus przyspieszył nas średnio o 10 lat” (Dukaj 2020). Technologia przekształciła się w opresyjne instrumentarium władzy, które - co stało się szczególnie widoczne w czasie pandemii - kształtuje temporalność jednostek w kierunku efektywności i przydatności. Technologia wywłaszcza czas jednostek. Istnieje ryzyko, że jeszcze prawdziwsze staną się tezy Jonathana Crarego (2015), który w książce 24/7. Późny kapitalizm i koniec snu twierdzi, że czas, który powinien być przeznaczony na czynności biologiczne, takie jak sen, jest zastępowany czasem korzystnym z punktu widzenia kapitalistycznej logiki wydajności i produktywności. Nieustanne podłączone do sieci jednostki, chcąc być efektywne w trakcie domowej kwarantanny, wszystkie obszary swojej aktywności całkowicie uzależniają od technologii, kumulatywnie zwiększającej tempo doświadczanego czasu. Niemające imion ani twarzy mechanizmy późnego kapitalizmu rosną w siłę, wykorzystując kryzysową sytuację pandemii i związany z nią rozwój technologii (Klein 2020). Jednocześnie wykluczają wszystkich tych, 
którzy mają ograniczony dostęp do technologii, i powodują wzrost nierówności społecznych.

\section{Czas pandemii a praca}

Eksperymentalna sytuacja wywołana przez COVID-19 uwidoczniła to, jak mocno czas i tempo życia są zależne od warunków zatrudnienia, na co wskazywał już Karol Marks, twierdząc, że czas ma wymiar klasowy (Łagosz 2012). Mechanizmy wiążące pracę i czas uobecniają się w jednostkowych doświadczeniach i różnią się w zależności od płci, wykonywanego zawodu, formy zatrudnienia, a także stosunku pracy. W czasie pandemii największe przeobrażenia $\mathrm{w}$ doświadczeniu czasu odczuli ci, którzy utracili pracę i znaleźli się tym samym w niekorzystnej sytuacji ekonomicznej. Za to dla osób nieposiadających wcześniej pracy niewiele się zmieniło. Niektóre zawody przestały w czasie pandemii istnieć, inne zaś zajęcia, takie jak praca pielęgniarek i dostawców żywności, okazały się niezbędne dla funkcjonowania całości społeczeństwa, nota bene odsłaniając bezużyteczność wielu najlepiej płatnych zawodów, o czym pisał już David Graever (2019), określając pozbawione społecznej wartości prace jako bullshit jobs. Pomiędzy tymi dwoma skrajnościami znalazły się telepraca i praca zdalna, które stały się jednym z powszechniejszych doświadczeń zawodowych w pandemicznej rzeczywistości.

Telepraca stanowi dla wielu poważne wyzwanie związane z naruszeniem tradycyjnego pojęcia „domu” traktowanego jako przestrzeń prywatna (Gądecki 2017). Za sprawą koronawirusa okazało się, że wiele czynności zawodowych można wykonywać bez wychodzenia $\mathrm{z}$ domu. Rosnąca liczba firm przekształciła pracę swoich pracowników w pracę zdalną, która była jedną z głównych przyczyn zmiany w doświadczeniu czasu. Dla osób z odpowiednimi warunkami mieszkaniowymi przejście z biur na tzw. home office początkowo było postrzegane jako szansa na zmniejszenie tempa życia dzięki przewidywanej mniejszej ilości pracy i możliwości zaoszczędzenia czasu chociażby na dojazdach do biura i wyjazdach służbowych. Pandemia była wręcz postrzegana jako czynnik przywracający kontrolę nad czasem pracy i czasem wolnym czy też nad rytmem dobowym, godzinami snu i godzinami czuwania (Ieven, Overwijk 2020). Sytuację tę znakomicie oddaje cytat: „Nagle cały świat odkrył, że pracować można metr od własnego łóżka w piżamie polanej kawą i z wygniecionymi od leżenia na poduszce włosami, popijając ze szklanki po porannej dawce tranu gin z tonikiem" (Wyrwik 2020). Wydawać by się mogło, że dzięki pracy z domu upadły dawne reżimy czasu pracy.

Okazało się jednak, że odcięcie się od wcześniej obowiązujących codziennych miar orientacji w czasie, związanych chociażby z godzinami pracy, spowodowało, że czas, w którym się znaleźliśmy, stał się nieścisły i nieprecyzyjny. Osoby, które zachowały pracę, ale przeszły w tryb zdalny, zaczęły borykać się z nieznanymi wcześniej problemami związanymi z zatarciem granic między czasem pracy 
a czasem wolnym, musiały na nowo uczyć się nawigować w niejasnych konturach krótszego dnia i tygodnia roboczego. Aby przeciwdziałać tej dezorientacji, w sieci pojawiły się liczne informacje, newslettery, poradniki i filmiki instruktażowe, takie jak „Lockdown Productivity: Spaceship You” (CGP Grey 2020). Pokazują one, za pomocą jakich technik pracować w izolacji, jak oddzielać czas pracy od czasu odpoczynku, aby móc wydajnie pracować $\mathrm{z}$ domu. $\mathrm{W}$ trakcie pandemii zaczęto także krytykować liczne treści i techniki związane z zarządzaniem sobą w czasie, które stanowią charakterystyczne dla późnego kapitalizmu umiejętności i praktyki nauczane w ramach licznych szkoleń i warsztatów. Przykładowo grafika o tytule „Working from home” (The CLIKK 2020) wskazuje na iluzoryczność tego typu technik stosowanych w branży cyfrowej. Jej treść nawiązuje do jednej z popularniejszych technik zarządzania czasem - macierzy Eisenhowera. Wyznacza ona podział na cztery kategorie: rzeczy ważnych, nieważnych, pilnych, niepilnych. W ironicznej grafice mamy do czynienia $z$ kategoriami odnoszącymi się do rzeczywistości pandemicznej: rzeczy dostępnych lub niedostępnych, a także rzeczy potrzebnych lub niepotrzebnych: 1) WiFi, kanapa i kawa stanowią obiekty potrzebne i dostępne; 2) etyka pracy związana z uczciwością, lojalnością i zaangażowaniem w pracę znajduje się wśród rzeczy potrzebnych, ale niedostępnych; 3) prokrastynacja i umiejętność odwlekania została sklasyfikowana jako coś, co jest dostępne, ale niepotrzebne; 4) natomiast ostatni, najbardziej humorystyczny element - spodnie - są wymienione jako obiekt nie należący ani do rzeczy potrzebnych, ani do dostępnych. Spodnie, a raczej ich brak, to element memiczny nawiązujący do kultury pracy z domu i możliwości wytwarzania iluzji profesjonalizmu zawodowego przez kamerkę internetową - nie trzeba być w pełni ubranym, żeby z pozoru wyglądać profesjonalnie (KOMIXXY.PL 2020).

Wydawać by się mogło, że w trakcie zbiorowej izolacji i dystansu społecznego osoby pracujące zdalnie powinny być mniej obciążone pracą. Jednak kilku rozmówców podzieliło się ze mną informacją, że ich pracodawcy na czas pandemii wprowadzili nowe, „bezsensowne” rozwiązania, mające być "jakąś namiastką" starych metod kontroli pracowników, takich jak karty ewidencji czasu pracy, rejestrujące czas spędzony na miejscu pracy. $Z$ uwagi na to, że niemożliwe stało się monitorowanie obecności w pracy, zaczęto zastanawiać się, w jaki sposób dokonywać ewidencji czasu pracy w dobie pandemii koronawirusa. Moja rozmówczyni Magda, trzydziestoletnia bibliotekarka, która podlega nadzorowi pracodawcy, zwierza się, że:

Dyrekcja wymyśla na siłę bezsensowne zadania. Przykładowo na początku przejścia na tryb pracy zdalnej moim zadaniem było pilnowanie, żeby do 7.30 każdy się zameldował wysyłając mi maila, zamiast odbijać się kartą przy wejściu do biblioteki. Te same maile miały być wysłane do wiadomości dyrekcji, kierownika, sekretariatu. Jak ktoś dzwonił i się zameldował tą formą to źle, musi być dowód na mailu. Potem dokładnie o godzinie 7.35 wysyłałam dyrekcji raport kto się zameldował. Nauczyłam się ustawiać automat mailowy i uczyłam tego innych jak mają to zrobić, żeby codziennie o 7.30 był od nich wysyłany mail automatycznie. 
Powyższy przykład wskazuje, jak w obszarze pracy technologia wykorzystywana jest do tworzenia się nowych reżimów czasu, dyscyplinujących jednostki. Celem tych nowych zarządzeń jest, aby opłacany czas był odmierzany także w warunkach telepracy, a także żeby był „czasem bez skaz i usterek, czasem wysokiej jakości, kiedy ciało bez ustanku przykłada się do swych zajęć" (Foucault 2009: 146).

\section{Nieokreśloność czasu pandemii}

Czas pandemiczny, choć wydawał się nieść obietnicę spowolnienia, doprowadził do jeszcze większego przyspieszenia. Mimo to niektórzy przeciwnicy kapitalizmu pragną widzieć w globalnym kryzysie szansę na spowolnienie, możliwość przeciwstawienia się dotychczas panującym w społeczeństwie reżimom czasu późnego kapitalizmu. Jednym $\mathrm{z}$ najbardziej znanych komentarzy utrzymanych $\mathrm{w}$ tym tonie był głośny esej Johna N. Graya w „The New Statesman” (Gray 2020). Wypowiedzi takie jak esej Graya nawiązują do powszechnego pragnienia zniwelowania pewnych współczesnych tendencji związanych z czasem, na przykład nadprodukcji. Wyrażają nadzieję takiej transformacji gospodarczo-społecznej, która przeorientowałaby rozwój cywilizacji na tzw. postwzrost (degrowth). Wybuch pandemii COVID-19 przez chwilę wydawał się być okazją na realizację postulatu ekologii czasu, wyrażającej potrzebę spowolnienia tempa życia (Cifrić 2010; Honoré 2011; Sztumski 2010; Strzelecka 2017a). Tego typu postawa była szczególnie wyraźna w początkowej fazie kwarantanny, kiedy liczne zakazy wywołały surrealistyczną atmosferę zawieszenia i poskutkowały nastaniem „ciszy czasu zarazy” (Dąbrowski 2000). Obok strachu pojawiło się poczucie ulgi, radość z pojawiającego się czasu wolnego i głosy nadziei na odnowę świata. Na ten korzystny aspekt COVID-19 zwrócił uwagę również Bruno Latour, który na łamach dziennika „Le Monde" odniósł się do sytuacji pandemicznej, koncentrując się na kryzysie ekologicznym i zmianach klimatycznych. W swojej wypowiedzi z dnia 25 marca $2020 \mathrm{r}$. stwierdził: „Po raz pierwszy od lat miliony ludzi uwięzionych w domach zyskują ten zapomniany luksus: czas na zastanowienie się i dostrzeżenie tego, co zazwyczaj powoduje niepotrzebne wiercenie się we wszystkie strony. Szanujmy ten długi i nieoczekiwany okres postu" (Latour 2020). Francuski antropolog i filozof wyraził w ten sposób nadzieję, że w nowo powstałym układzie relacji czas pandemiczny odegra ważną rolę w kształtowaniu rozumienia negatywnych skutków późnego kapitalizmu, współczesnej gospodarki i technologii, a także doprowadzi do sprzeciwu wobec zawrotnej prędkości życia współczesnych społeczeństw. Postawa Latoura wpisuje się w narrację o potencjalnych skutkach pandemii, takich jak społeczne przewartościowanie, wzrost wrażliwości ekologicznej, docenienie społecznie pożytecznych zawodów, odbudowa sąsiedzkiej troski i aktywizmu lokalnego. W podobnym tonie wypowiedziała się również Bińczyk: 
Sytuacja zamrożenia w wyczekiwaniu i utraty najbliższej przyszłości może być w pewnym sensie zbawienna, bo zatrzymuje nasz pęd chomików na kołowrotku, pęd do kontynuacji postawy business as usual (...) Na naszych oczach zatrzymała się hiperkonsumpcyjna gospodarka wzrostu PKB, która ciągle musi być w ruchu, przemieszczać się i pędzić nie wiadomo dokąd, choć raczej w złym kierunku, przynajmniej wedle badaczy systemów Ziemi. Dostaliśmy możliwość refleksji, zatrzymania się, podważenia dotychczasowego „zdrowego rozsądku” (Bińczyk 2020).

Nie da się jednak określić jednego stabilnego rytmu czasu pandemii. Mimo to nie ulega wątpliwości, że regulacje narzucone przez władzę chwilowo zmieniły znane nam dotychczas rytmy życia i wpłynęły na jakość przeżywanego czasu i tempo jego upływu. Sytuacja spowodowana przez COVID-19 pokazała, że doświadczenie czasu jest ściśle powiązane z decyzjami politycznymi, czynnikami cywilizacyjnymi i technologicznymi, z organizacją pracy, życia społecznego i gospodarczego. W tych eksperymentalnych warunkach uwypukliły się mechanizmy związane z kształtowaniem czasu w późnym kapitalizmie. Koronawirus pomógł nam zrozumieć, że dotychczas we współczesnej gospodarce czas społeczny był kształtowany głównie w odniesieniu do trzech kategorii: władzy, technologii i pracy, które w czasie pandemii uległy poważnym przeobrażeniom, zmieniając tym samym społeczne rytmy życia. Na tę zależność wskazały dokonane obserwacje i zasłyszane wypowiedzi rozmówców. Pandemia pozwoliła spojrzeć z dystansu na to, jak pracujemy, a także wyraźniej dostrzec, że czas zegarowy, związany z rytmem pracy, nie jest czasem „obiektywnym”, lecz sposobem sprawowania kontroli nad temporalnością jednostek, strategią nacisku, która jest zmienna w zależności od panujących warunków i mechanizmów władzy. Dzięki koronawirusowi otworzyliśmy się również na nowe możliwości technologiczne powodujące, że nasza temporalna rzeczywistość ulega nieustannym przeobrażeniom. Na koniec warto przytoczyć słowa Piotra Borowca (2013: 12), który uważa, że „okresy wielkich zmian społecznych i kulturowych pociągają za sobą (...) zmiany w społecznym doświadczaniu czasu", a także opinię Elżbiety Tarkowskiej, dla której badania czasu społecznego są uprawnionym sposobem mówienia o nadchodzących przemianach społecznych (Tarkowska 1999: 343). Obserwacja czasu w pandemii jest więc niezbędna nie tylko do wyodrębnienia cech współczesnego społeczeństwa, ale również do rozumienia mechanizmów życia społecznego i prognozowania przyszłych zmian kulturowych. Tym samym antropologiczne studia nad czasem można potraktować jako element antropologii przewidującej (anticipatory anthropology) zajmującej się projektowaniem scenariuszów przyszłości poprzez analizę współczesnych wydarzeń (Strzelecka 2013: 265). 


\section{Bibliografia}

Adam B.

1995 TimeWatch: The Social Analysis of Time, Cambridge.

2008 Czas społeczeństwa przemysłowego $i$ władza, w: Socjologia codzienności, red. P. Sztompka, M. Bogunia-Borowska, Kraków, s. 487-513.

Agamben G.

2008 Stan wyjątkowy, przeł. M. Surma-Gawłowska, Kraków.

Appadurai A.

2005 Nowoczesność bez granic. Kulturowe wymiary globalizacji, przeł. Z. Pucek, Kraków.

Bińczyk E., Sutowski M.

2020 Bińczyk: Na naszych oczach zatrzymała się hiperkonsumpcyjna gospodarka wzrostu, https://krytykapolityczna.pl/swiat/michal-sutowski-ewa-binczyk-uwiad-wyobrazni-koronawirus-szansa-wywiad (dostęp: 16.06.2020).

Borowiec P.

2013 Czas polityczny po rewolucji, Kraków.

Bryson V.

2016 Time, power and inequalities, w: Time, temporality and global politics, red. A. Holm, i in., Bristol, s. 102-114.

CGP Grey

2020 Lockdown Productivity: Spaceship You, YouTube, www.youtube.com/ watch?v=snAhsXyO3Ck (dostęp: 16.06.2020).

Cifrić I.

2010 Ecology of time. Time as Integrative and Disintegrative Factor, „Socijalna Ekologija” nr 19, s. 5-32.

Crary J.

2015 24/7. Późny kapitalizm i koniec snu, przeł. D. Żukowski, Kraków.

Davis $M$.

2013 Hurried lives: Dialectics of time and technology in liquid modernity, „Thesis Eleven" nr 118 (1), s. 7-18.

Dąbrowski P.

2000 Cisza, hałas, sen, https://macondofundacja.weebly.com/cisza.html (dostęp: 16.06.2020).

Dukaj J.

2020 Tak wymienia się rdzeń duszy, „Gazeta Wyborcza”, 9 maja, www.wyborcza.pl/ magazyn/7,124059,25929950,tak-wymienia-sie-rdzen-duszy-nowy-esej-jacka-dukaja.html (dostęp: 16.06.2020).

Fabian J.

2002, Time and the Others: How Anthropology Makes Its Object, New York.

Foucault M.

2009 Nadzorować i karać, przeł. T. Komendant, Warszawa.

Fraser J.T.

1987 Time the Familiar Stranger, Amherst.

Gądecki J. i in.

2017 Tu się pracuje! Socjologiczne studium pracy zawodowej prowadzonej w domu na zasadach telepracy, Kraków. 
Gell A.

1996 The Anthropology of Time: Cultural Constructions of Temporal Maps and Images, Oxford-Washington.

Gray J.

2020 Why this crisis is a turning point in history, "The New Statesman”, www.newstatesman.com/international/2020/04/why-crisis-turning-point-history (dostęp: 16.06.2020).

Graever D.

2019 Praca bez sensu: teoria, przeł. M. Denderski, Warszawa.

Hassan R.

2009 Crisis Time: Networks, Acceleration and Politics within Late Capitalism, „CTheory” https://journals.uvic.ca/index.php/ctheory/article/view/14767 (dostęp: 16.06.2020).

2010 Globalization and the "temporal turn": recent trends and issues in time studies, „The Korean Journal of Policy Studies”, nr 2 (25), s. 83-102.

Honoré C.

2011 Pochwała powolności. Jak zwolnić tempo i cieszyć się życiem, przeł. K. Umiński, Warszawa.

Hutchings K.

2008 Time and World Politics, Manchester.

Ieven B., Overwijk J.

2020 We created this beast. The political ecology of COVID-19, https://www.eurozine. com/we-created-this-beast/ (dostęp: 16.06.2020).

Jędrysik $M$.

2020 Raport OKO.press. Jak rząd PiS poradził sobie w I fazie walki z koronawirusem, https://oko.press/raport-oko-press-jak-rzad-pis-poradzil-sobie-w-i-fazie-walki-z-koronawirusem/ (dostęp: 16.06.2020).

Kaur H.

2020 The pandemic is messing with our concept of time. CNN health, https://edition. cnn.com/2020/04/28/health/what-day-is-it-pandemic-wellness-trnd/index.html (dostęp: 16.06.2020).

Klein N.

2020 Koronawirus jest doskonałym kataklizmem dla kapitalizmu kataklizmowego, przeł. K. Szadkowski, https://www.praktykateoretyczna.pl/artykuly/naomi-klein-koronawirus-jest-doskonalym-kataklizmem-dla-kapitalizmu-kataklizmowego/ (dostęp: 16.06.2020).

Klein S.

2009 Czas. Przewodnik użytkownika, przeł. K. Żak, Warszawa.

KOMIXXY.PL

2020 Praca zdalna https://m.komixxy.pl/1500581 (dostęp: 16.06.2020).

Kopka J.

2013 Zdrowie psychiczne a czasowy wymiar życia społecznego, „Acta Universitatis Lodziensis. Folia Sociologica" nr 45, s. 193-208.

Kornbluh A.

2020 Akademicka koronawirusowa doktryna szoku, przeł. M. Moll, „Praktyka Teoretyczna”, https://www.praktykateoretyczna.pl/artykuly/akademicka-koronawirusowa-doktryna-szoku/ (dostęp: 16.06.2020).

Latour B.

2020 Bruno Latour - „Kryzys zdrowotny to szansa by przygotować się na zmiany klimatyczne”, przeł. M. Pospiszyl, „Praktyka Teoretyczna” https://www.praktykateoretyczna. 
pl/artykuly/bruno-latour-kryzys-zdrowotny-to-szansa-by-przygotowac-sie-na-zmiany-klimatyczne/ (dostęp: 16.06.2020).

Łagosz M.

2012 Marks, praca i czas, Warszawa.

Munn N.D.

1992 The Cultural Anthropology of Time: A Critical Essay, "Annual Review of Anthropology" nr 21, s. 93-123.

Narodowe Centrum Kultury,

2020 Program dotacyjny „Kultura w sieci”. NABÓR WNIOSKÓW,www.nck.pl/dotacje-i-stypendia/dotacje/programy-dotacyjne-nck/kultura-w-sieci/aktualnosci/nabor-wnioskow-2020 (dostęp: 16.06.2020).

Nowotny $\mathrm{H}$.

2005 Politics of Time: The Distribution of Work and Time, w: Time. The Modern and Postmodern Experience, Cambridge, s. 102-131.

Pickering K.

2004 Decolonizing Time Regimes: Lakota Conception of Work, Economy, and Society, „American Anthropologists” nr 106 (1), s. 85-97.

Rosa $\mathrm{H}$.

2013 Social Acceleration: A New Theory of Modernity, New York.

Sabelis I.

2007 The Clock-Time Paradox. Time Regimes in the Network Society, w: 24/7. Time and Temporality in the Network Society, red. R. Hassan, R.E. Purser, Stanford, s. 255-277.

Strang V.

2015 On the matter of time, „Interdisciplinary Science Reviews” nr 2 (40), s. 101-123.

Strzelecka C.

2013 Anticipatory anthropology - anthropological future study, „Prace Etnograficzne” nr 41 (4), s. 261-269.

2017a Między czasem ekologicznym a ekologia czasu w kulturze przyspieszenia, „Studia Etnologiczne i Antropologiczne" nr 17, s. 272-289.

2017b Zwrot temporalny. Przegląd wybranych publikacji i stanowisk, „Zeszyty Etnologii Wrocławskiej” nr 1(26), s. 109-124.

Sztumski W.

2010 Turboświat, pułapka przyspieszenia i ekologia czasu, w: Czas w życiu człowieka, red. K. Popiołek, Katowice, s. 23-37.

Tarkowska E.

1987 Czas w społeczeństwie. Problemy, tradycje, kierunki badań, Wrocław.

1992 Czas w życiu Polaków. Wyniki badań, hipotezy, impresje, Warszawa.

1999 Społeczeństwo różnych rytmów: przypadek Polski na tle tendencji globalnych, w: Imponderabilia wielkiej zmiany. Mentalność, wartości i więzi społeczne czasów transformacji, red. P. Sztompka, Warszawa-Kraków, s. 343-359.

Tarkowski A.

2020 Infodemia, praca zdalna i utrzymywanie więzi społecznych. Internet w obliczu pandemii, https://centrumcyfrowe.pl/czytelnia/infodemia-praca-zdalna-i-utrzymywanie-wiezi-spolecznych-internet-w-obliczu-pandemii/?fbclid=IwAR0kY9bkd8iqhMDni8 dZS0GUdyUyAz5w5-_7gZQ8Pvr7wvs0xA9_2819lmw (dostęp: 16.06.2020). 


\section{The CLIKK}

2020 This is how COVID-19 could change the world of work for good, www.weforum. org/agenda/2020/04/here-s-how-coronavirus-has-changed-the-world-of-work-covid19-adam-grant/ (dostęp: 16.06.2020).

Tomlinson J.

2007 The Culture of Speed. The Coming of Immediacy, Los Angeles.

Trybulec M.

2009 Nowe media a kulturowe doświadczenie czasu. Uwagi krytyczne na marginesie teorii akceleracji czasu, „Annales Universitatis Mariae Curie-Skłodowska Lublin-Polonia” nr 34, s. 7-19.

Virilio P.

2000 The Information Bomb, London.

Wyrwik A.

2020 Kwarantanny ciąg dalszy, czyli trudna sztuka nicnierobienia, „Przekrój”, https:// przekroj.pl/kultura/kwarantanny-ciag-dalszy-czyli-trudna-sztuka-nicnierobieniaanna-wyrwik (dostęp: 16.06.2020).

2020 Kwarantanny ciąg dalszy, czyli trudna sztuka nicnierobienia, „Przekrój”, https:// przekroj.pl/kultura/kwarantanny-ciag-dalszy-czyli-trudna-sztuka-nicnierobieniaanna-wyrwik (dostęp: 16.06.2020). 